\title{
Load Self-Sensing Control Scheme for Telemanipulation - Part 2: Experiment
}

\author{
Mateusz Saków, Karol Miądlicki \\ West Pomeranian University of Technology, Szczecin, Faculty of Mechanical Engineering and Mechatronics, 19 Piastów Avenue, \\ 70-310 Szczecin, Poland
}

\begin{abstract}
The paper presents a novel approach to a control design of bilateral teleoperation systems with force-feedback, dedicated only for a weight sensing. The problem statement, analysis of papers up to date, and the scope of the study are presented. The new control unit for a master-slave system with force-feedback was based on a NARX model. The model was used to subtract a value of force in the force-feedback communication channel that the system might generate during free-motion. The new approach to a control design was validated on a test-stand of a simple rotating pneumatic manipulator arm. The paper presents the modeling procedure of the experimental setup and the model used in the study. Two experiments are described to demonstrate the control unit of the master-slave system with force-feedback.
\end{abstract}

Keywords: telemanipulation, force-feedback, inverse modeling, telerobotics, remote control

\section{Introduction}

Researcher's attempts to ensure safe operation of various machines had led to the development of master-slave control systems with force-feedback. The applications of master-slave systems are widespread, including performing tasks in environments hostile to man, contaminated sites, in the depths of oceans and seas, radioactive interiors of nuclear power plants, and even medical rehabilitation. Most of master-slave systems are unilateral [9, 10 , $19,23,25,32,33$ ]; i.e. a device that is being controlled (slave) should behave exactly as the device that controls it (master). However, as research continued, it was noticed that the operator, that enters into interaction with the master subsystem/manipulator should be able to feel the haptic effect of the environment on the slave subsystem side. The problem posed significant challenges in its practical application, due to large distances and the inevitable time delay $[1-5,7,8,12,15,16,18-20,22-26,28,35$, $38,39]$. This specific branch of robotics faces many challenges that have been tackled by scientists all over the world for many years. The main problem that arises in the communication channel between actuation devices is a time delay, which inhibit their communication. The problem is particularly pronounced, while sending information over large distances. Another challenge is the stability of such systems, given known or unknown delays in the communication channel.

\section{Autor korespondujący: \\ Mateusz Saków, mateusz.sakow@zut.edu.pl}

Artykuł recenzowany

nadesłany 12.02.2018 r., przyjęty 23.02.2018 r.
So far, the main presented control schemes for bilateral teleoperation systems with force-feedback have some defects. These defects mean the use a large number of sensors mediating between the environment and the bodies of the slave manipulator, especially in rotary joints. A situation in which the environment affects one degree of freedom in accordance with that degree of freedom, is relatively simple by using a single sensor. However, where the design of the manipulator depends on many degrees of freedom, and moves in the three-dimensional space, use of single or multiple sensors could be considered as expensive, or not adequate for the proper operation of such a system.

Sensor-less and self-sensing, large appliances are rare, even in scientific literature. There are only couple of papers, rising problem of inverse modeling used in self-sensing control unit of bilateral teleoperators. This work and papers $[6,11-14,17,19$, 21-31, 36, 37], are addressing this problem. First paper [37], presents a method for the impedance control of a pneumatic linear actuator for tasks involving contact interaction. The presented method takes an advantage of the natural compliance of pneumatic actuators. The central notion of the method is that by departing from a stiff actuation system, low-bandwidth acceleration measurements can be used in lieu of high-bandwidth force measurements. Second paper [34], presents teleoperated minimally invasive surgery systems, measurement and display of a sense of force to the operator. In this paper, a master-slave system for laparoscopic surgery, which can provide force-feedback to the surgeon without using force sensors was proposed. Pneumatic cylinders were used as the actuator of the manipulators to achieve this. Both papers are based on the same control methodology, the impedance control. In [37] control methodology contained an inner loop to control the pressure on two sides of a pneumatic cylinder, while an outer loop enforces an impedance relationship between external forces and motion and commands desired pressures to the inner loop. The inner loop enforces the natural compliance of the pneumatic actuator by controlling both the sum and difference of the pressures on both sides of 
the pneumatic actuator. In [34], a bilateral dynamic control system was designed using a neural network for acquisition of the inverse dynamics. The obtained inverse dynamics was used as a feed-forward controller and to estimate the external force from the differential pressure of the cylinders.

The paper presents a pneumatic manipulator that is an introduction to the work on the hydraulic crane car which is much bigger then devices in the presented literature. In this project, the operator needed to feel the crane load, but also the feeling of a haptic contact was required. The contact situation between the unmovable object of an environment and the Slave manipulator, must be realized in the way that the system will push back the operator by resisting his motion. Introduction to work on much bigger devices means consideration of disadvantages like long hydraulic pipes which are also included in the presented test-stand. The problem of high friction values and many other which will occur during further work has to be overcome during preliminary test-stand.

Also in this paper, a part of impedance control was used. This part is an inverse model of the manipulator structure corresponding to the manipulator operation without any environmental impact on the slave subsystem. Based on this fact it is possible to obtain relatively accurate information about the environmental impact on the specific DoF of the slave manipulator. This important feature eliminates the need to use a sensor (susceptible component) between the body of the manipulator and the environment, or between the actuator and the manipulator body.

An important feature of this approach on the design of the control system is that the value of the impact of the environment is transmitted to a specific master manipulator degree of freedom, as a response from the equivalent DoF in the slave manipulator, but without using geometrical relationships resulting from the construction of the manipulator. Difference between impedance control $[34,37]$, in this paper system is relatively simple. The control unit is not controlling the pressure inside an actuator chamber. Measured pressure is only being subtracted by the estimated pressure which estimated pressure is calculated by the inverse model of subsystem Slave.

\section{The Experimental Test Stand}

In the pneumatic test stand, mechanical features of a slave and a master subsystem are completely identical. The exoskeleton Master subsystem was attached to the operator's elbow. The subsystem slave was mounted to a strong and heavy table. Thus, it was not necessary to do the calculations of pressure in the feedback resulting from differences in the mass and dimensions of the master and the slave. In the context of the experimental setup, the mass of the human limb was considered as negligible. The experimental setup is presented in Fig. 1.

The Figure 1 presents the manipulator arm with its drive system which was taken into account in the mathematical model of a pressure in chambers. There is a stationary base plate (1), which is fixed to the table. The bending actuator (5) and its extension bend the manipulator arm. The straightening actuator (2) and its extension straighten the manipulator arm (3). The characteristic manipulator arm is the movable part of the slave subsystem (3). The arm rotates at the articulated wrist, where a measuring encoder was mounted.

Mounting pneumatic drives in the presented way, was not accidental. Using two drives, affects the symmetry of the piston areas which, as it turned out,
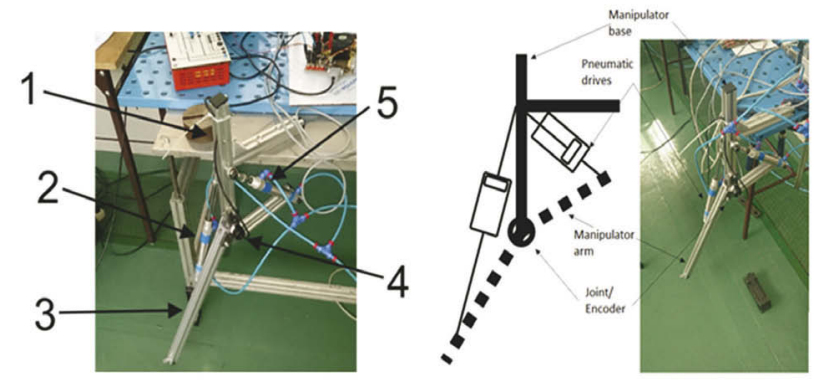

Fig. 1. Experimental test stand Rys. 1. Stanowisko badawcze

considerably improved the quality and position tracking ability of the entire subsystem slave. Most of signals in the system are analogue signals like pressure measurement, and discrete for the encoders and valves. Encoders that were used to build the test stand had a number of pulses equal to 500 per revolution. The pressure gauge used to measure pressure in the system had a maximum measurement value of $10 \mathrm{bar}$, proportionally sensing the pressure as $1 \mathrm{~V}$ to $10 \mathrm{~V}$.

The slave subsystem as it is possible to see in Fig. 2, there are three pneumatic control signals of solenoid valves $\mathrm{V}_{1}, \mathrm{~V}_{2}$ and controllable variable orifice $\mathrm{SD}$. The $\mathrm{V}_{1}$ signal is the left coil voltage signal of $5 / 3$ switching valve, $V_{2}$ is the right coil voltage signal of the same switching valve and the SD signal, which is analogue and controls the degree of throttle opening - the variable orifice. The pressure sensor $P$ is placed between the $5 / 3$ Valve and the variable orifice. As it turned out during tests, it is possible to estimate pressure in both piston chambers using single pressure sensor, with a respect to a pneumatic scheme in the Fig. 2.

In the case of a master subsystem it was easy to use a pressure control valve $P_{z}$ which controls the air pressure on the basis of the set value from force-feedback communication channel. Then, the pressure will only reach destined piston chambers using on/off valves: $\mathrm{V}_{4}$ and $\mathrm{V}_{5}$ (Fig. 3), the additional pressure sensors $\mathrm{Pm}_{1}$ and $\mathrm{Pm}_{2}$ finally were not used in control scheme.

\section{Inverse modeling of the test stand}

Based on the manipulator arm, a geometrical and dynamic model of the slave and master subsystem was built, as shown in Fig. 4. The geometrical model of rotating arm was dependent on the dimensions of actuators. The dimensions of each actuator cause

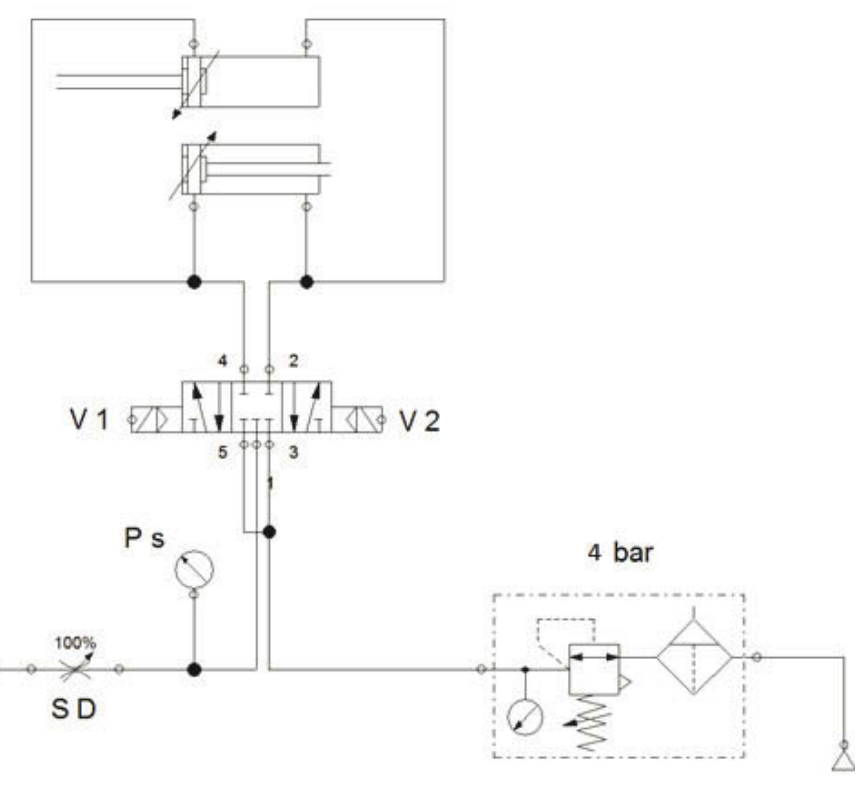

Fig. 2. Pneumatic scheme of Slave manipulator

Rys. 2. Schemat pneumatyczny układu napędowego podsystemu Slave 


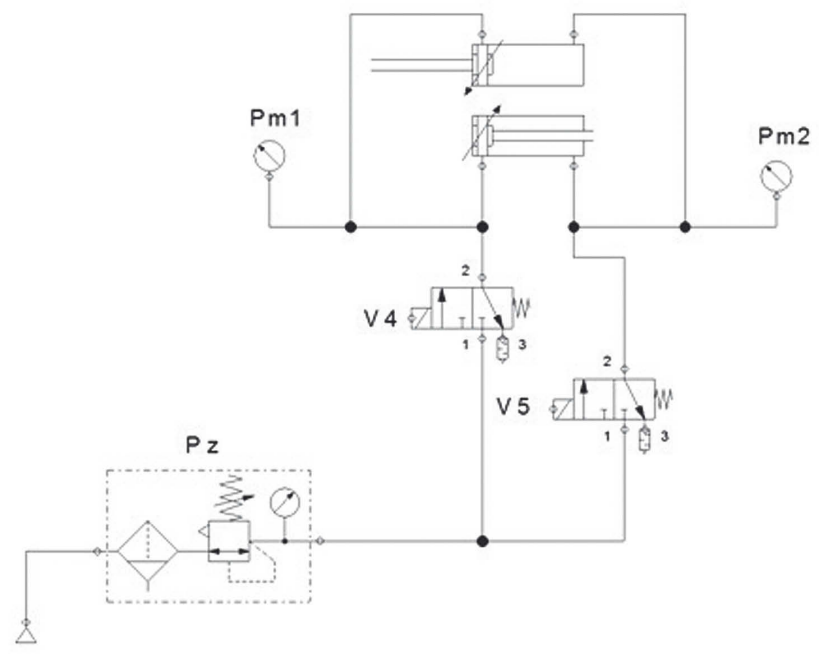

Fig. 3. Pneumatic scheme of Master manipulator

Rys. 3. Schemat pneumatyczny układu napędowego podsystemu Master

movement of the entire manipulator arm. To build a model which will behave exactly like the one in the Fig. 1, requires the use of geometrical relationships among actuator, base, and rotational arm of the manipulator, as shown in the Fig. 4.

Model in the Fig. 4 describes the estimated pressure in free motion, in the time domain by equation (1):

$P_{\text {est }}(t)=\frac{G_{2} e \sin \left(\beta_{2}(t)\right)-G_{1} \frac{d}{2} \sin \left(\beta_{1}(t)\right)-\frac{1}{3}\left(m_{1} c^{2}+4 m_{2} b^{2}\right) \varepsilon(t)}{A_{2} b \cos \left(\frac{\pi}{2}-\gamma_{2}\right)-A_{1} b \sin \left(\gamma_{1}\right)}$

where $A_{1}$ and $A_{2}$ are the areas of pistons - first and second actuator, $\varepsilon(t)$ is the angular acceleration of the manipulator arm, $G_{1}$ and $G_{2}$ are the gravity forces applied to the body of manipulator. Rest variables are angles and radiuses used for derive the equation (1) (Fig. 4).

As it turned out during tests, simple geometric and mechanical model was not enough to properly estimate pressure inside the piston chamber. This model was incorporated to a structure of nonlinear autoregressive model with exogenous input - NARX. The nonlinear part of model NARX was based on a binary tree. This model has estimated relatively well the pressure, relative to the simple equation (1).

\section{Experiment}

After the identification was carried out, the model of the slave subsystem tests were conducted to verify the operation of the system. The aim of the first measurement was to check how the system would behave, given no interaction with the environment and the interaction appears. The external interaction of the environment which occurs for the nonlinear manipulator arm is gravity and resistance to motion, and in this particular i sztywnego kontaktu tem was able to transmit adequate information to the feedback with a relatively large time delay of $0.5 \mathrm{~s}$. It can even be seen in the Fig. 5. This is due to the compressibility of the medium in the system, and is not the fault of the control system, whose

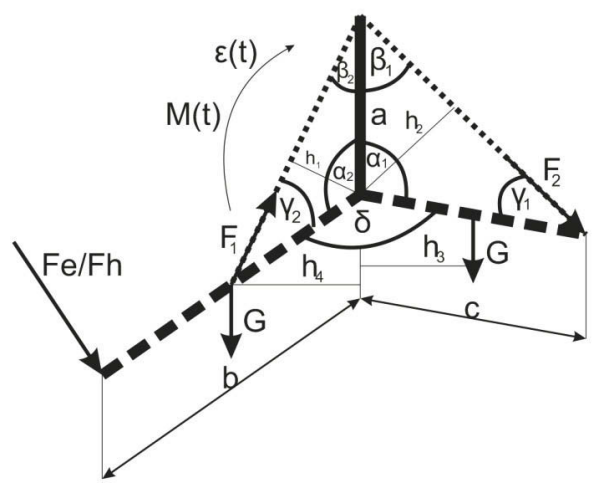

Fig. 4. Geometrical relationship of manipulator arm

Rys. 4. Zależności geometryczne ramienia manipulatora

case, the friction and resistance of air surrounding the manipulator. However, even these component data were modeled within the structure of the NARX model. Owing to this, such a data can be considered as negligible when conducting certain runs by the slave subsystem of the manipulator, as they exert the same influence both on the real object and on the model. Diagrams of the first experiment are presented in the Fig. 5.

The contact phase can be seen in the runs presented in the Fig. 5 between 3 to 12 seconds. The control system precisely mapped the maximum pressure of 2 bar. The maximum pressure of 2 bar in force feedback is the effective pressure, resulting from using the control method that relies on pressure changes in the system. The maximum pressure in the system was 6 bar. However, it is counteracted by the pressure of 4 bar, and the whole system stiffens. The value of 2 bar means that the sys-
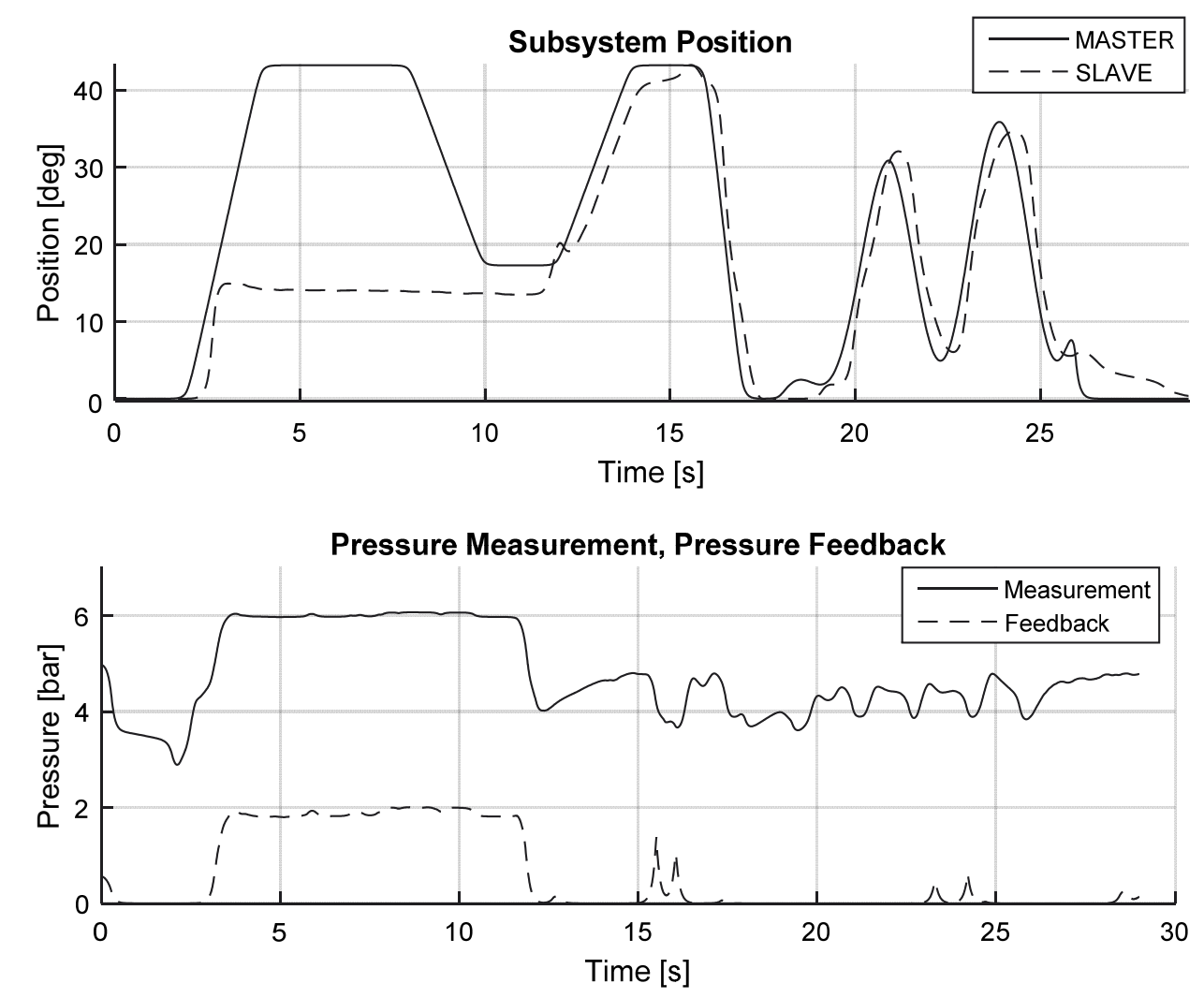

Fig. 5. Master-slave system test-stand; first measurement during free motion and contact operation Rys. 5. Wyniki eksperymentalne manipulatora pneumatycznego; pomiar pierwszy podczas ruchu swobodnego 

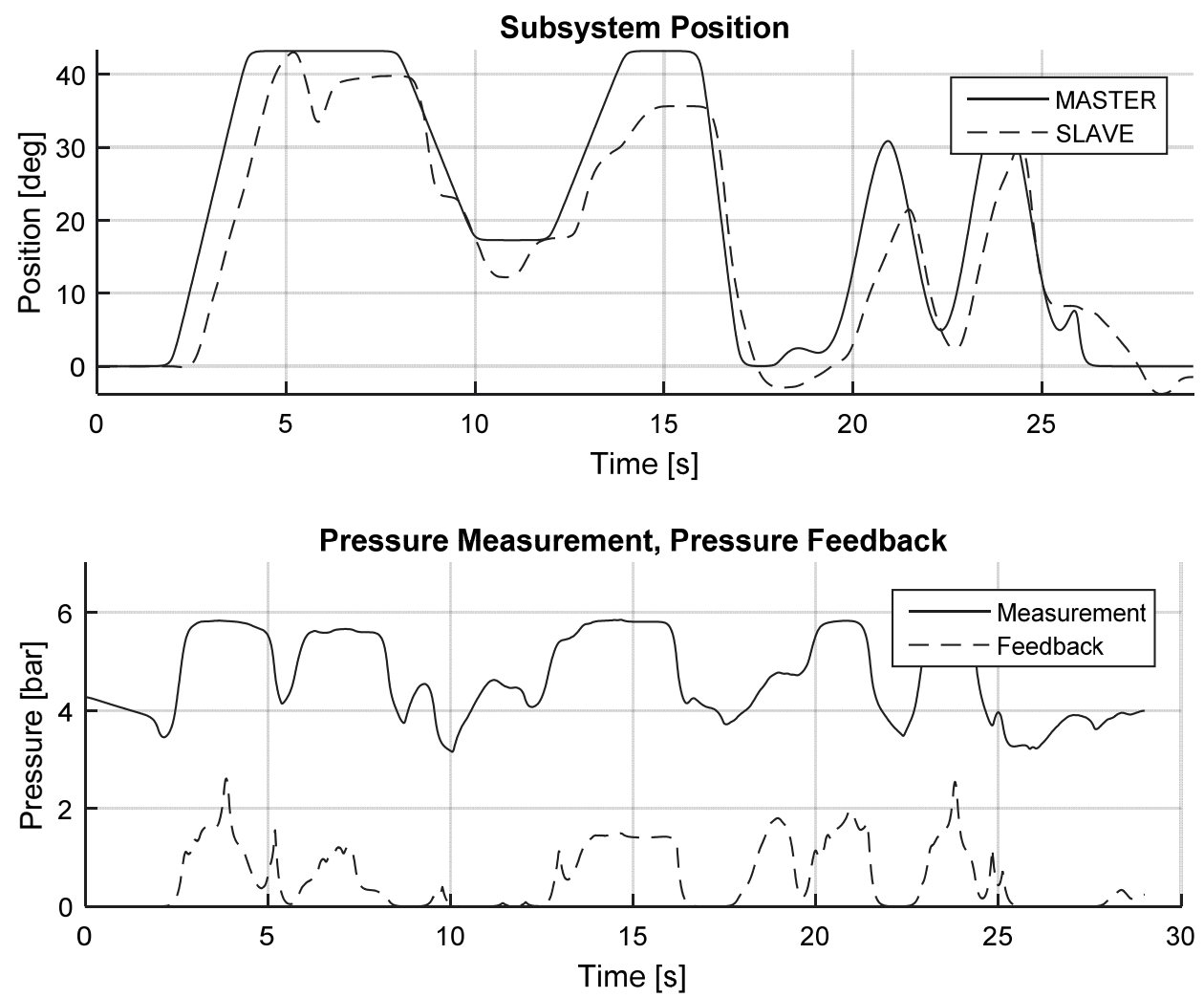

Fig. 6. Master-slave system test-stand; second measurement during load sensing

Rys. 6. Wyniki eksperymentalne manipulatora pneumatycznego; pomiar drugi podczas wykrywania

obciążenia

clocking frequency was set a $10 \mathrm{kHz}$. Also, the aim of the first experiment was to check if the system would show the maximum pressure at the moment, when it will encounter an object it would not be able to move. The results of the experiment are shown in Fig. 5.

The second test was focused on goal, if the system was able to feel the load of inertia, which was attached to the slave manipulator arm. Run can be seen in the Fig. 6 .

The estimated pressure, this time was seriously distorted, but around 15 second of lower run at steady state it delivered the information with only $5 \%$ error to the expected value. The main cause of distorted pressure feedback was simple PID controller and the disturbed position tracking ability with high change of manipulator arm inertia. Imperfect model also had an impact on the distortion of the value in the force-feedback communication channel. In the future, the ability of position tracking will be improved, but on different hydraulic device.

\section{Conclusion}

The paper raises a problem of self-sensing, sensorless bilateral teleoperation. The control unit was based on a NARX model of subsystem Slave. This study was focused on the tests of a simple pneumatic manipulator. The tests were conducted on a short distance of one meter, so that any delay in the communication channel could be considered as negligible. But the width of a pipe delivering air pressure between actuator chamber and pressure sensor effected a delay of around $0.5 \mathrm{~s}$. The additional difficulty of the main task of the study was the fact that the rotating robotic arm was driven by two linear pneumatic actuators. Two linear pneumatic actuators, were mounted in the presented way to overcome the difference in a cylinder surface. This difference caused serious modeling problems. The actuators were also mounted so that their characteristics would be strongly nonlinear; i.e. the radial length of the actuator retraction axis to the rotation axis of the arm would not be constant, but would be dependent on the configuration of the robot arm at a given time - feature of car cranes.

An additional challenge was posed by the pneumatic system itself. One disadvantage of pneumatic systems may be the fact that they are quite difficult to control, when it comes to position tracking. This fact is caused by a high air compressibility which translates into low stiffness of the mechanical structure. For position tracking it was used a simple PID controller cooperated with a controllable orifice. The controller was tuned during system operation. The simple PID controller was used because this paper was not focused on ability of position tracking by the system, but on a proof that the system is able to estimate the values of force-feedback without force sensor and impedance control method.

\section{Acknowledgments}

The work was carried out as part of PBS3/A6/28/2015. "The use of augmented reality, interactive voice systems and operator interface to control a crane", which was financed by NCBiR.

\section{References}

1. Ben-Dov D., Salcudean S.E., A force-controlled pneumatic actuator for use in teleoperation masters, [in:] Proceedings of 1993 IEEE International Conference on Robotics and Automation, 938-943,

DOI: 10.1109/ROBOT.1993.292264.

2. Ferrell W.R., Delayed Force Feedback, "Human Factors: The Journal of the Human Factors and Ergonomics Society", Vol. 8, No. 5, 1966, 449-455,

DOI: $10.1177 / 001872086600800509$.

3. Guerriero B., Book W., Haptic Feedback Applied to Pneumatic Walking, ASME 2008 Dynamic Systems and Control Conference, American Society of Mechanical Engineers, 591-597, DOI: $10.1115 /$ DSCC2008-2185.

4. Hannaford B., Stability and performance tradeoffs in bi-lateral telemanipulation, [in:] Proceedings of 1989 IEEE 
International Conference on Robotics and Automation, Vol. 1763, 1764-1767,

DOI: $10.1109 /$ ROBOT.1989.100230.

5. Hastrudi-Zaad K., Salcudean S.E., On the use of local force feedback for transparent teleoperation, [in:] Proceedings of 1999 IEEE International Conference on Robotics and Automation, Vol. 1863, 1863-1869, DOI: 10.1109/ROBOT.1999.770380.

6. Hogan N., Impedance Control: An Approach to Manipulation: Part II - Implementation, "Journal of Dynamic Systems, Measurement, and Control", Vol. 107, No. 1, 1985, 8-16, DOI: $10.1115 / 1.3140713$.

7. Kim W.S., Developments of new force reflecting control schemes and an application to a teleoperation training simulator, [in:] Proceedings of 1992 IEEE International Conference on Robotics and Automation, Vol. 1412, 1992, 1412-1419, DOI: 10.1109/ROBOT.1992.220152.

8. Kim W.S., Hannaford B., Fejczy A.K., Force-reflection and shared compliant control in operating telemanipulators with time delay, "IEEE Transactions on Robotics and Automation", Vol. 8, No. 2, 1992, 176-185,

DOI: $10.1109 / 70.134272$.

9. Miądlicki K., Pajor M., Overview of user interfaces used in load lifting devices, "International Journal of Scientific \& Engineering Research", Vol. 6, No. 9, 2015, 1215-1220.

10. Miądlicki K., Pajor M., Real-time gesture control of a CNC machine tool with the use Microsoft Kinect sensor, "International Journal of Scientific \& Engineering Research", Vol. 6, No. 9, 2015, 538-543.

11. Miadlicki K., Pajor M., Sakow M., Loader Crane Working Area Monitoring System Based on LIDAR Scanner, "Advances in Manufacturing", Springer, 2018, 465-474, DOI: 10.1007/978-3-319-68619-6_45.

12. Miądlicki K., Pajor M., Saków M., Ground plane estimation from sparse LIDAR data for loader crane sensor fusion system, 22nd International Conference on Methods and Models in Automation and Robotics (MMAR), IEEE, Międzyzdroje, Poland, 2017, 717-722,

DOI: 10.1109/MMAR.2017.8046916.

13. Miądlicki K., Pajor M., Saków M., Real-time ground filtration method for a loader crane environment monitoring system using sparse LIDAR data, 2017 IEEE International Conference on INnovations in Intelligent SysTems and Applications (INISTA), IEEE, 2017, 207-212, 10.1109/ INISTA.2017.8001158.

14. Miądlicki K., Saków M., The use of machine vision to control the basic functions of a CNC machine tool using gestures, Czasopismo Techniczne, Vol. 12, 2017, 213-229, DOI: $10.4467 / 2353737 X C T .17 .221 .7764$.

15. Najdovski Z., Nahavandi S., Fukuda T., Design, Development, and Evaluation of a Pinch-Grasp Haptic Interface, IEEE/ASME Transactions on Mechatronics, Vol. 19, No. 1, 2014, 45-54,

DOI: 10.1109/TMECH.2012.2218662.

16. Nguyen T., Leavitt J., Jabbari F., Bobrow J.E., Accurate Sliding-Mode Control of Pneumatic Systems Using Low-Cost Solenoid Valves, IEEE/ASME Transactions on Mechatronics, Vol. 12, No. 2, 2007, 216-219, DOI: $10.1109 /$ TMECH.2007.892821.

17. Ningbo Y., Hollnagel C., Blickenstorfer A., Kollias S.S., Riener R., Comparison of MRI-Compatible Mechatronic Systems With Hydrodynamic and Pneumatic Actuation, IEEE/ASME Transactions on Mechatronics, Vol. 13, No. 3, 2008, 268-277, DOI: 10.1109/TMECH.2008.924041.

18. Noritsugu T., Pulse-width modulated feedback force control of a pneumatically powered robot hand, International Symposium of Fluid Control and Measurement, Tokyo, 1985, 47-52.
19. Pajor M., Miądlicki K., Saków M., Kinect Sensor Implementation in Fanuc Robot Manipulation, "Archives of Mechanical Technology and Automation", Vol. 34, No. 3, 2014, 35-44.

20. Polushin I.G., Takhmar A., Patel R.V., Projection-Based Force-Reflection Algorithms With Frequency Separation for Bilateral Teleoperation, IEEE/ASME Transactions on Mechatronics, Vol. 20, No. 1, 2015, 143-154,

DOI: 10.1109/TMECH.2014.2307334.

21. Saków M., Marchelek K., Parus A., Miądlicki K., Control scheme without force sensors for load sensing in telemanipulation systems with force-feedback, "Journal of Machine Construction and Maintenance. Problemy Eksploatacji", No. 3, 2017, 21-30.

22. Saków M., Miądlicki K., Parus A., Self-sensing teleoperation system based on 1-dof pneumatic manipulator, "Journal of Automation, Mobile Robotics and Intelligent Systems", Vol. 11, No. 1, 2017, 64-76.

23. Saków M., Pajor M., Parus A., Estimation of environmental forces impact on remote control system with force-feedback and upper limb kinematics (in Polish), "Modelowanie Inżynierskie", Vol. 27, No. 58, 2016, 113-122.

24. Saków M., Pajor M., Parus A., Self-sensing control system determining the environmental force influence on the manipulator during the operation of the telemanipulation system (in Polish), "Projektowanie Mechatroniczne - Zagadnienia Wybrane", Katedra Robotyki i Mechatroniki, Akademia Górniczo-Hutnicza w Krakowie, 2016, 139-150.

25. Saków M., Parus A., Sensorless control scheme for teleoperation with force-feedback, based on a hydraulic servo-mechanism, theory and experiment, "Measurement Automation Monitoring", Vol. 62, No. 12, 2016, 417-425.

26. Saków M., Parus A., Miądlicki K., Predictive method of force determination in the force-feedback communication channel of remotely controlled system (in Polish), "Modelowanie inżynierskie", Vol. 31, No. 62, 2017, 88-97.

27. Sakow M., Parus A., Pajor M., Miadlicki K., Unilateral Hydraulic Telemanipulation System for Operation in Machining Work Area, Advances in Manufacturing, Springer, 2018, 415-425, DOI: 10.1007/978-3-319-68619-6_40.

28. Saków M., Parus A., Pajor M., Miądlicki K., Nonlinear inverse modeling with signal prediction in bilateral teleoperation with force-feedback, 2017 22nd International Conference on Methods and Models in Automation and Robotics (MMAR), IEEE, Międzyzdroje, Poland, 2017, 141-146, DOI: 10.1109/MMAR.2017.8046813.

29. Seraji H., Colbaugh R., Adaptive force-based impedance control, IROS '93. Proceedings of the 1993 IEEE/RSJ International Conference on Intelligent Robots and Systems, 1993, Vol. 1533, 1537-1544,

DOI: $10.1109 /$ IROS.1993.583844.

30. Seul J., Hsia T.C., Bonitz R.G., Force tracking impedance control of robot manipulators under unknown environment, "IEEE Transactions on Control Systems Technology", Vol. 12, No. 3, 2004, 474-483,

DOI: 10.1109/TCST.2004.824320.

31. Stateczny K., Pajor M., Miadlicki K., Sakow M., MEMS based system for controlling and programing industrial manipulator Fanuc s-420F using gestures, "Problemy Eksploatacji", 4/2017, 107, 81-89.

32. Stuart K.D., Majewski M., Intelligent Opinion Mining and Sentiment Analysis Using Artificial Neural Networks, International Conference on Neural Information Processing, Springer, Istanbul, Turkey, 2015, 103-110, DOI: 10.1007/978-3-319-26561-2_13.

33. Stuart K.D., Majewski M., Trelis A.B., Intelligent semantic-based system for corpus analysis through hybrid probabi- 
listic neural networks, International Symposium on Neural Networks, Springer, 2011, 83-92,

DOI: $10.1007 / 978-3-642-21105-8 \_11$.

34. Tadano K., Kawashima K., Development of 4-DOFs forceps with force sensing using pneumatic servo system, Proceedings 2006 IEEE International Conference on Robotics and Automation, ICRA 2006, 2250-2255, DOI: 10.1109/ROBOT.2006.1642038.

35. Taghizadeh M., Ghaffari A., Najafi F., Improving dynamic performances of $P W M$-driven servo-pneumatic systems via a novel pneumatic circuit, "ISA Transactions", Vol. 48, No. 4, 2009, 512-518,

DOI: $10.1016 /$ j.isatra.2009.05.001.

36. Yokokohji Y., Yoshikawa T., Bilateral control of master-slave manipulators for ideal kinesthetic coupling-formulation and experiment, IEEE Transactions on Robotics and Automation, Vol. 10, No. 5, 1994, 605-620, DOI: $10.1109 / 70.326566$.
37. Yong Z., Barth E.J., Impedance Control of a Pneumatic Actuator for Contact Tasks, Proceedings of the 2005 IEEE International Conference on Robotics and Automation, 2005, 987-992,

DOI: 10.1109/ROBOT.2005.1570245.

38. Zhang T., Jiang L., Wu X., Feng W., Zhou D., Liu H., Fingertip Three-Axis Tactile Sensor for Multifingered Grasping, "IEEE/ASME Transactions on Mechatronics", Vol. 20, No. 4, 2014, 1875-1885,

DOI: 10.1109/TMECH.2014.2357793.

39. Zhou M., Ben-Tzvi P., RML Glove - An Exoskeleton Glove Mechanism With Haptics Feedback, IEEE/ASME Transactions on Mechatronics, Vol. 20, No. 2, 2015, 641-652, DOI: 10.1109/TMECH.2014.2305842.

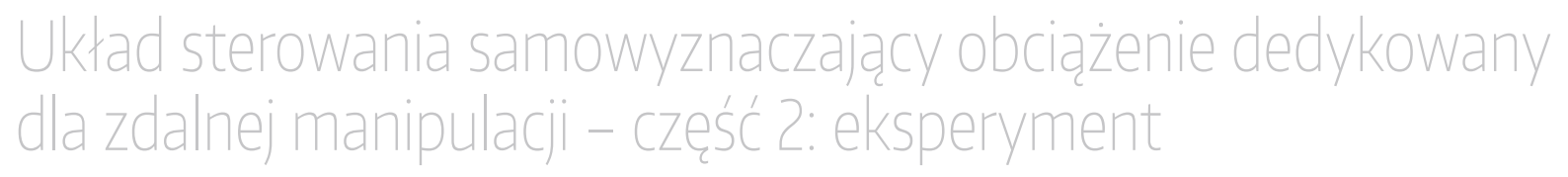

\section{Streszczenie: W artykule przedstawiono podejście do projektowania sterowania dwustronnych systemów zdalnej operacji ze sprzężeniem zwrotnym, przeznaczonym wyłącznie do wykrywania obciążenia. Opis problemu, analiza dotychczasowych osiągnięć badawczych oraz zakres badania zostały zawarte w pracy. Nowy projekt jednostki sterującej dla systemu Master-Slave z siłowym sprzężeniem zwrotnym oparty został na modelu NARX. Model został użyty do odejmowania wartości siły w kanale komunikacyjnym sprzężenia zwrotnego, który jest generowany przez system podczas ruchu swobodnego. Efektywność działania nowego podejścia została potwierdzone na prostym pneumatycznym stanowisku badawczym obrotowego ramienia manipulatora. W pracy przedstawiono procedurę modelowania i konfiguracji eksperymentalnej, a także model zastosowany w układzie sterowania. Opisane są dwa eksperymenty przeprowadzone na układzie sterowania systemu master- slave z siłowym sprzężeniem zwrotnym.}

Słowa kluczowe: zdalna manipulacja, siłowe sprzężenie zwrotne, odwrotne modelowanie, telerobotyka, zdalne sterowanie

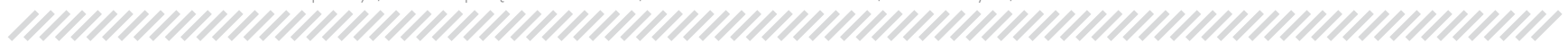

\section{Mateusz Saków, MSc Eng.}

mateusz.sakow@zut.edu.pl

He started his higher education in 2010, rece. ived the B.S. degree in Mechatronics Engineering from the West Pomeranian University of Technology, Szczecin in 2013. In 2015 received the M.S. degree in Mechanical Engineering also from West Pomeranian University, Szczecin. His research interests include bilateral teleoperation systems, telemanipulation, inverse modeling, model-free signal prediction and filtration/differentiation. From 2014 he has been working in. research projects conducted at the Institute of Mechanical Technology at the Faculty of Mechanical Engineering and Mechatronics. From 2015 PhD student in Department of Mechatronics Systems. From 2015 a student member of ASME.

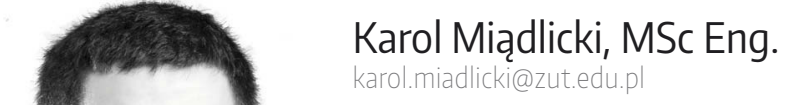

He started his higher education in 2008 , received the B.S. degree in Automation and Robotics Engineering from West Pomeranian University of Technology, Szczecin in 2011. In 2013 received the M.S. degree in Automation and Robotics Engineering also from West Pomeranian University of Technology, Szczecin. His research interests include gesture controls, image processing and

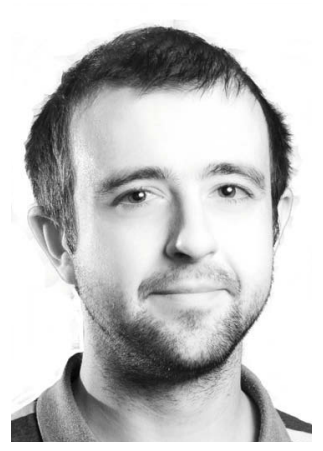
CNC control. From 2013 he has been working in research projects conducted at the Institute of Mechanical Technology at the Faculty of Mechanical Engineering and Mechatronics. From 2013 PhD student in Department of Mechatronics Systems. From 2015 a student member of IEEE. 